ISSN 2080-1653

Dol 10.24917/20801653.334.17

\title{
MAŁGORZATA MARKOWSKA
}

Uniwersytet Ekonomiczny we Wrocławiu, Polska

Wroclaw University of Economics and Business, Poland

\section{DANUTA STRAHL}

Akademia WSB w Dąbrowie Górniczej, Polska

WSB University in Dąbrowa Górnicza, Poland

\section{ELŻBIETA SoBCZAK}

Uniwersytet Ekonomiczny we Wrocławiu, Polska

Wroclaw University of Economics and Business, Poland

\section{Peter HlaváčEK}

Uniwersytet Jana Evangelisty Purkynego, Usti nad Labem, Czechy

Jan Evangelista Purkyne University, Usti nad Labem, Czech Republic

\section{Podobieństwo struktur zatrudnienia w krajach Unii Europejskiej w latach 2008-2017 - ocena dynamiki}

\section{Similarities in Employment Structure of the European Union Countries in the Years 2008-2017 - Assessment of Dynamics}

\begin{abstract}
Streszczenie: Celem pracy jest identyfikacja grup krajów Unii Europejskiej podobnych co do struktury zatrudnienia w ujęciu dynamicznym, z wykorzystaniem metody aglomeracyjnej najdalszego sąsiedztwa. W ocenie wykorzystano informacje o zatrudnieniu w krajach Unii Europejskiej, dokumentowane m.in. w podziale na 10 sekcji: rolnictwo, przemysł, budownictwo, handel, informacja, finanse i ubezpieczenia, nieruchomości, usługi profesjonalne, sfera budżetowa, kultura. Analizowane są podobieństwa struktur zatrudnienia w krajach Unii Europejskiej w latach 2008-2017. Dla każdego roku osobno wyznaczono macierz odległości (niepodobieństwa) struktur zatrudnienia pomiędzy krajami UE. Wykorzystując tę macierz, zastosowano taksonomiczną metodę aglomeracyjną najdalszego sąsiedztwa, która po metodzie Warda jest drugą co do skuteczności metodą odkrywania grup podobnych w zbiorach analizowanych obiektów. Wybór metody zdeterminowany był wykorzystaną miarą odległości, jak również jej elastycznością - na podstawie analizy porównawczej uzyskanych dendrogramów - poziomu cięcia dendrogramu. W pracy, po obserwacji otrzymanych drzew klasyfikacyjnych, przyjęto odległość krytyczną jako 0,15. Oznacza to, że dwie grupy obiektów mogą być połączone, jeżeli najdłuższa odległość pomiędzy obiektami należącymi do różnych podgrup nie przekracza 0,15 . Przy cięciu dendrogramu na poziomie 0,15 otrzymano dla każdego roku podział krajów UE na grupy zbliżone co do struktury zatrudnienia. Okazało się, że Luksemburg oraz Rumunia we wszystkich latach stanowiły osobne, jednoelementowe grupy. Dla pozostałych krajów wyróżniono trzy zasadnicze grupy. Poddano analizie zmiany składu grup w czasie oraz dynamikę średnich struktur dla grup.
\end{abstract}

1 Praca wykonana w ramach grantu Narodowego Centrum Nauki: 2015/17/B/HS4/01021 oraz środków przyznanych Wydziałowi Zarządzania Akademii WSB w Dąbrowie Górniczej w ramach dotacji na utrzymanie potencjału badawczego, Wydziałowi Ekonomii, Zarządzania i Turystyki Uniwersytetu Ekonomicznego we Wrocławiu w ramach dotacji na utrzymanie potencjału badawczego i grantu Czeskiej Fundacji Nauki nr 18-11299S. 


\begin{abstract}
The aim of the paper is to identify groups of European Union countries similar in terms of employment structures, applying the furthest neighbour agglomerative clustering procedure with dynamic approach. The employment data for UE countries is reported in 10 sections: agriculture, industry, construction, trade, information, finance and insurance, real estate, professional services, administration, culture. A research presented covers the period of 2008-2017. Distance matrices for the dissimilarity of employment structures in EU countries have been calculated separately for each year. Then, the furthest neighbour method has been applied (which is next to Ward method in group identification efficiency) with the critical agglomerative distance of 0.15 . It means that two groups can be merged if the furthest distance between objects belonging to different groups is not bigger than 0.15. Cutting dendrograms in this way we found that the resulting groups of countries for consecutive years are rather similar. Luxemburg and Romania formed a single-object groups in every year. Three main groups have been identified within other EU countries. Dynamics of these groups content, and average structures is discussed.
\end{abstract}

Słowa kluczowe: kraje UE; struktury; Unia Europejska; zatrudnienie

Keywords: employment; EU countries; European Union; structures

Otrzymano: 31 stycznia 2019

Received: 31 January 2019

Zaakceptowano: 16 lipca 2019

Accepted: 16 July 2019

Sugerowana cytacja / Suggested citation:

Markowska, M., Strahl, D., Sobczak, E., Hlaváček, P. (2019). Podobieństwo struktur zatrudnienia w krajach Unii Europejskiej w latach 2008-2017 - ocena dynamiki. Prace Komisji Geografii Przemysłu Polskiego Towarzystwa Geograficznego, 33(4), 283-294. doi: 10.24917/20801653.334.17

\title{
WSTĘP
}

Wyodrębnienie grup obiektów podobnych, o względnie jednorodnych strukturach, umożliwia identyfikację elementów charakterystycznych, które różnicują grupy. Analizy, po uprzednim grupowaniu, umożliwiają m.in. podejmowanie decyzji w sprawie stanu i perspektyw rozwoju obiektów. Wykorzystanie miar podobieństwa (niepodobieństwa) w połączeniu z metodą grupowania pozwala na badanie przeobrażeń strukturalnych obiektów gospodarczych w czasie i przestrzeni, tj.: w różnych okresach dla jednego obiektu, w jednym momencie dla grupy obiektów, w wielu momentach dla wielu obiektów. Podobieństwo (niepodobieństwo) obiektów rozumiane jako podobieństwo (niepodobieństwo) w sensie wartości zmiennych zaobserwowanych w tych obiektach jest tym większe, im większa (mniejsza) jest wartość miary (Walesiak, 1982).

Analizy strukturalne, oceny podobieństwa i zmian w strukturach są wszechobecne w literaturze przedmiotu i dotyczą wszystkich aspektów procesów społeczno-gospodarczych. Jednym z najczęściej podejmowanych tematów badawczych jest struktura zatrudnienia (rozpatrywana na różnym szczeblu podziału terytorialnego), która określa podział ludności według zatrudnienia w sektorach, sekcjach, branżach i gałęziach gospodarki.

Struktura zatrudnienia uwarunkowana jest poziomem rozwoju gospodarczego, zasobami (naturalnymi, kapitałowymi i ludzkimi), wynika z kształtowanej latami specjalizacji jednostki terytorialnej, potrzeb rynku wewnętrznego i makrootoczenia. Ważnym elementem badań stają się prace na temat charakteru zmian w europejskich strukturach zatrudnienia, wraz z próbami poszukiwania wzorców strukturalnych zmian zatrudnienia w Europie (Acemoglu, 2002; Goos, Manning, Salomons, 2009; Fernández-Macías, 2012; Markowska, Sokołowski, Strahl, 2014; Castellano, Musella, Punzo, 2017; 2019). 
Celem pracy jest próba wydzielenia grup krajów Unii Europejskiej podobnych ze względu na struktury zatrudnienia w sekcjach, w ujęciu dynamicznym (okres 20082017), z wykorzystaniem metody aglomeracyjnej najdalszego sąsiedztwa.

\section{METODA WYKORZYSTANA W OCENIE PODOBIEŃSTWA STRUKTUR}

Schemat postępowania - wykorzystaną metodykę badania przedstawiono poniżej.

1. Ustalenie wskaźników struktury dla każdego roku $(\mathrm{t}=1, \ldots, 10)$.

2. Wyznaczenie macierzy odległości (niepodobieństwa) struktur zatrudnienia D pomiędzy krajami UE w każdym momencie t, z wykorzystaniem miary niepodobieństwa struktur (Chomątowski, Sokołowski, 1978) określonej wzorem:

$$
d_{i j}=1-\sum_{l=1}^{m} \min \left\{w_{i l}, w_{j l}\right\}
$$

i, j - numery obiektów (krajów) (i, j = 1, 2, ..., 28),

$\mathrm{l}$ - numer składnika struktury $(\mathrm{l}=1,2, \ldots, 10)$,

m - liczba składników struktury,

w - wskaźniki struktury.

3. Zastosowanie do realizacji zagadnienia taksonomicznego [Y,Zt] (podziału krajów UE na grupy o podobnych strukturach, na podstawie macierzy D) metody aglomeracyjnej najdalszego sąsiedztwa (np. Grabiński, 1992; Gelbard, Goldman, Spiegler, 2007), dla każdego roku osobno.

4. Ustalenie poziomu cięcia dendrogramów.

5. Identyfikacja grup krajów - w każdym roku osobno - ze względu na podobieństwo struktur.

6. Ocena zmian składu grup i przeciętnych struktur.

\section{ZMIENNE DO OCENY PODOBIEŃSTWA STRUKTUR ZATRUDNIENIA W KRAJACH UE}

W ocenie podobieństwa struktur zatrudnienia w krajach Unii Europejskiej wykorzystano dane Eurostatu z lat 2008-2017 na temat liczby osób zatrudnionych (Employment by age, economic activity and NUTS 2 regions [lfst_r_lfe2en2], Eurostat, 2018), dotyczące osób w wieku 15-64 lata. Informacje te prezentowane są w układzie 10 sekcji (podano nazwy skrócone wraz ze stosowanymi w tabelach akronimami):

S1: rolnictwo - rolnictwo, leśnictwo i rybołówstwo (Agriculture, forestry and fishing),

S2: przemysł - przemysł (bez budownictwa) (Industry (except construction)),

S3: budownictwo - budownictwo (Construction),

S4: handel - handel hurtowy i detaliczny, transport, usługi noclegowe i żywieniowe (Wholesale and retail trade, transport, accommodation and food service activities),

S5: informacja - informacja i komunikacja (Information and communication),

S6: finanse i ubezpieczenia - działalność finansowa i ubezpieczeniowa (Financial and insurance activities),

S7: nieruchomości - działalność związana z nieruchomościami (Real estate activities),

S8: usługi profesjonalne - działalność naukowo-techniczna; usługi administracyjne i usługi wsparcia (Professional, scientific and technical activities; administrative and support service activities), 
S9: sfera budżetowa - administracja publiczna, obrona narodowa, edukacja, ochrona zdrowia i pomoc społeczna (Public administration, defense, education, human health and social work activities),

S10: kultura - sztuka, rozrywka i rekreacja, inne usługi, aktywność gospodarstw domowych, organizacje ponadregionalne (Arts, entertainment and recreation; other service activities; activities of household and extra-territorial organizations and bodies).

Liczby zatrudnionych w poszczególnych sekcjach w krajach UE dały podstawę do ustalenia wskaźników struktury w latach 2008-2017.

\section{WYNIKI GRUPOWANIA}

Przeprowadzona dziesięciokrotnie - dla każdego roku oddzielnie - opisana wcześniej procedura badawcza pozwoliła wydzielić grupy krajów podobnych z uwagi na strukturę zatrudnienia. W tabeli 1 przedstawiono wyniki obliczeń średnich (nieważonych) struktur dla roku 2008. Takie ustalenia poczyniono dla grup otrzymanych na podstawie danych z poszczególnych lat. We wszystkich tabelach przyjęto konwencję oznaczania czcionką pogrubioną wartości największej (wśród grup), a podkreślano najmniejszą.

Tabela 1. Średnie wskaźniki struktury zatrudnienia w sekcjach, w grupach - rok 2008

\begin{tabular}{|l|c|c|c|c|c|c|c|c|c|c|}
\hline \multicolumn{1}{|c|}{ Grupy } & S1 & S2 & S3 & S4 & S5 & S6 & S7 & S8 & S9 & S10 \\
\hline A & 0,0219 & 0,1652 & $\underline{0,0727}$ & 0,2333 & $\mathbf{0 , 0 3 6 0}$ & 0,0324 & $\mathbf{0 , 0 0 8 8}$ & 0,0914 & 0,2885 & 0,0497 \\
\hline B & 0,0633 & $\mathbf{0 , 2 5 7 8}$ & 0,0929 & 0,2454 & 0,0231 & 0,0222 & 0,0061 & 0,0606 & 0,1913 & 0,0372 \\
\hline C & 0,0405 & 0,1452 & $\mathbf{0 , 1 0 8 1}$ & 0,2727 & 0,0293 & 0,0399 & 0,0064 & 0,0885 & 0,2044 & 0,0648 \\
\hline D & 0,0835 & 0,1764 & 0,1075 & $\mathbf{0 , 2 7 3 4}$ & 0,0192 & 0,0192 & 0,0058 & 0,0595 & 0,2071 & 0,0484 \\
\hline Luksemburg & $\underline{\mathbf{0 , 0 1 6 9}}$ & $\underline{0,0749}$ & 0,0779 & $\underline{0,1910}$ & 0,0337 & $\mathbf{0 , 1 0 6 2}$ & 0,0055 & $\mathbf{0 , 0 9 4 2}$ & $\mathbf{0 , 3 0 2 6}$ & $\mathbf{0 , 0 9 7 2}$ \\
\hline Rumunia & $\mathbf{0 , 2 4 9 8}$ & 0,2488 & 0,0841 & 0,1990 & $\underline{0,0134}$ & $\underline{0,0124}$ & $\underline{0,0017}$ & $\underline{0,0320}$ & $\underline{\mathbf{0 , 1 3 9 8}}$ & $\underline{\mathbf{0 , 0 1 9 0}}$ \\
\hline
\end{tabular}

Objaśnienie: w tabeli czcionką pogrubioną zaznaczono wartości średnie najwyższe w danej sekcji, a podkreślone są wartości najniższe.

Źródło: opracowanie własne na podstawie danych Eurostatu (2018)

Ucięcie dendrogramu na poziomie 0,15 (wartość ustalona na podstawie analizy wzrokowej wszystkich 10 dendrogramów, obserwacji struktury grup oraz „skoków” odległości aglomeracyjnej; przyjęto tę samą dla wszystkich lat) pozwoliło wyodrębnić sześć grup:

A: Belgia, Dania, Francja, Wielka Brytania, Holandia, Szwecja, Niemcy, Finlandia, Malta (w roku 2008 najwyższe przeciętne udziały w sekcjach informacje i nieruchomości, a najmniejsze w budownictwie),

B: Bułgaria, Chorwacja, Polska, Czechy, Słowacja, Słowenia, Estonia, Węgry, Włochy (najwyższy średni udział zatrudnionych w przemyśle),

C: Irlandia, Austria, Hiszpania, Cypr (relatywnie najwyższy średni udział zatrudnionych w budownictwie),

D: Grecja, Łotwa, Litwa, Portugalia (najwyższy średni udział zatrudnionych w handlu) oraz dwie osobne, jednoelementowe grupy, które tworzyły Luksemburg i Rumunia (szczegółowo opisane w dalszej części). 
Zbiorcze zestawienie przypisania krajów do grup przedstawiono w tabeli 2. Pogrubioną czcionką oznaczono te kraje, które stanowią trzon grupy, a kursywą te, które były w danej grupie nie dłużej niż $n$ - 2 lata (ta zasada w przypadku grupy C stosowana jest osobno dla dwóch podokresów - 2008-2012 oraz 2013-2017)

Tabela 2. Przyporządkowanie krajów do trzech zasadniczych podgrup (A, B, C) oraz grup jednoelementowych (L i R)

\begin{tabular}{|c|c|c|c|c|c|c|c|c|c|c|}
\hline Kraje & 2008 & 2009 & 2010 & 2011 & 2012 & 2013 & 2014 & 2015 & 2016 & 2017 \\
\hline $\begin{array}{l}\text { Dania, Francja, Holandia, } \\
\text { Wielka Brytania, Szwecja }\end{array}$ & A & A & A & $\mathbf{A}$ & A & $\mathbf{A}$ & $\mathbf{A}$ & A & A & $\mathbf{A}$ \\
\hline Belgia & A & & A & A & A & A & A & A & A & A \\
\hline Finlandia & $A$ & & A & A & $A$ & A & & & A & $A$ \\
\hline Malta & $A$ & & & & $A$ & & & & & $A$ \\
\hline Niemcy & $A$ & & & & $A$ & $B$ & & & $B$ & $A$ \\
\hline Czechy, Słowenia, Słowacja & B & B & B & B & B & B & B & B & B & B \\
\hline Polska & B & B & B & B & B & B & B & B & & B \\
\hline Węgry & B & B & B & & B & B & B & B & B & B \\
\hline Bułgaria & $B$ & $B$ & $B$ & $B$ & $B$ & $B$ & & $B$ & & \\
\hline Chorwacja & $B$ & $B$ & $B$ & $B$ & $B$ & $B$ & & $B$ & & \\
\hline Estonia & $B$ & $B$ & $B$ & & $B$ & $B$ & & $B$ & $B$ & \\
\hline Włochy & $B$ & $B$ & $B$ & & & $B$ & & & $B$ & \\
\hline Portugalia & & & $B$ & & & $B$ & & & $B$ & \\
\hline Łotwa & & $\mathbf{C}$ & $\mathbf{C}$ & $\mathbf{C}$ & $\mathbf{C}$ & $B$ & & $B$ & & \\
\hline Litwa & & C & C & $\mathrm{C}$ & C & $B$ & & $B$ & & \\
\hline Austria & $\mathrm{C}$ & $\mathrm{C}$ & $\mathrm{C}$ & & $\mathrm{C}$ & $B$ & & & & \\
\hline Hiszpania & C & $\mathrm{C}$ & C & C & C & C & C & $\mathrm{C}$ & C & C \\
\hline Grecja & & $\mathrm{C}$ & $\mathrm{C}$ & $\mathrm{C}$ & $\mathrm{C}$ & $\mathrm{C}$ & C & C & $\mathrm{C}$ & C \\
\hline Irlandia & C & $\mathrm{C}$ & $\mathrm{C}$ & $\mathrm{C}$ & $A$ & C & & & $C$ & \\
\hline Cypr & & & & & & & C & $\mathrm{C}$ & $\mathrm{C}$ & C \\
\hline Luksemburg & $\mathbf{L}$ & $\mathbf{L}$ & $\mathbf{L}$ & $\mathbf{L}$ & $\mathbf{L}$ & $\mathbf{L}$ & $\mathbf{L}$ & $\mathbf{L}$ & $\mathbf{L}$ & $\mathbf{L}$ \\
\hline Rumunia & $\mathbf{R}$ & $\mathbf{R}$ & $\mathbf{R}$ & $\mathbf{R}$ & $\mathbf{R}$ & $\mathbf{R}$ & $\mathbf{R}$ & $\mathbf{R}$ & $\mathbf{R}$ & $\mathbf{R}$ \\
\hline
\end{tabular}

Źródło: opracowanie własne

Kraje bez żadnego przyporządkowania w tabeli 2 znajdowały się w innych mało licznych i zmiennych grupach, niekoniecznie wszystkie w tej samej. Cztery kraje w badanym okresie wędrowały po różnych grupach. Były to Niemcy, Malta, Irlandia i Austria. Ich struktury zatrudnienia można uznać za relatywnie najmniej ustabilizowane.

Oceniając cały analizowany okres, należy wskazać, że w każdym z otrzymanych dendrogramów - przygotowanych dla danych z lat 2008-2017 - jednoelementowe grupy tworzyły Luksemburg i Rumunia.

Luksemburg to kraj, w którym we wszystkich latach najwyższe było zatrudnienie (w sensie najwyższego udziału) w finansach i ubezpieczeniach- było to $10-13 \%$, podczas gdy w innych grupach kilkakrotnie (!) mniejsze (tabela 3 i rycina 1). Podobnie najwyższy był w Luksemburgu w analizowanym okresie udział zatrudnionych w kulturze. Jednocześnie we wszystkich latach Luksemburg miał najmniejszy ze wszystkich 
grup krajów udział zatrudnionych w rolnictwie, przemyśle i handlu. W pracy oceniano też tendencje średnich wskaźników struktury w otrzymanych grupach. Istotne (na poziomie 0,05 ) współczynniki kierunkowe trendów liniowych dla Luksemburga otrzymano dla udziału zatrudnionych $w$ przemyśle (średnioroczny spadek: $b=-0,0024$ ), w usługach profesjonalnych (średnioroczny wzrost: $b=0,0033$ ) i kulturze (wzrost: $\mathrm{b}=0,0014$ ). Struktura zatrudnienia w Luksemburgu jest stabilna, o czym świadczą małe wartości miary zmian struktury.

Tabela 3. Wskaźniki struktury zatrudnienia w sekcjach - Luksemburg

\begin{tabular}{|c|c|c|c|c|c|c|c|c|c|c|c|}
\hline Rok & S1 & $S 2$ & $S 3$ & $S 4$ & $S 5$ & $S 6$ & $S 7$ & $S 8$ & $S 9$ & S10 & $\begin{array}{c}\text { Zmiana } \\
\text { struktury }\end{array}$ \\
\hline 2008 & $\underline{0,0169}$ & $\underline{0,0749}$ & 0,0779 & $\underline{0,1910}$ & 0,0337 & $\mathbf{0 , 1 0 6 2}$ & 0,0055 & $\mathbf{0 , 0 9 4 2}$ & $\mathbf{0 , 3 0 2 6}$ & $\mathbf{0 , 0 9 7 2}$ & - \\
\hline 2009 & $\underline{0,0129}$ & $\underline{0,0711}$ & $\underline{0,0582}$ & $\underline{0,1790}$ & 0,0339 & $\mathbf{0 , 1 3 0 8}$ & 0,0072 & 0,0931 & 0,3088 & $\mathbf{0 , 1 0 5 0}$ & 0,0405 \\
\hline 2010 & $\underline{0,0106}$ & $\underline{0,0670}$ & $\underline{0,0670}$ & $\underline{0,1604}$ & $\mathbf{0 , 0 4 1 4}$ & $\mathbf{0 , 1 3 0 1}$ & 0,0058 & $\mathbf{0 , 1 0 1 2}$ & 0,3083 & $\mathbf{0 , 1 0 8 4}$ & 0,0277 \\
\hline 2011 & $\underline{0,0116}$ & $\underline{0,0672}$ & 0,0667 & $\underline{0,1677}$ & $\mathbf{0 , 0 3 8 9}$ & $\mathbf{0 , 1 2 9 7}$ & 0,0060 & 0,0941 & 0,3082 & 0,1098 & 0,0103 \\
\hline 2012 & $\underline{0,0127}$ & $\underline{0,0630}$ & 0,0639 & $\underline{0,1588}$ & $\mathbf{0 , 0 4 0 7}$ & $\mathbf{0 , 1 2 8 2}$ & 0,0066 & $\mathbf{0 , 0 9 9 3}$ & $\mathbf{0 , 3 1 5 0}$ & $\mathbf{0 , 1 1 2 0}$ & 0,0176 \\
\hline 2013 & $\underline{0,0148}$ & $\underline{0,0610}$ & 0,0601 & $\underline{0,1607}$ & $\mathbf{0 , 0 4 0 1}$ & $\mathbf{0 , 1 2 9 4}$ & 0,0070 & 0,1063 & 0,3127 & $\mathbf{0 , 1 0 8 0}$ & 0,0126 \\
\hline 2014 & $\underline{0,0135}$ & $\underline{0,0636}$ & $\underline{0,0467}$ & $\underline{0,1587}$ & $\mathbf{0 , 0 4 5 0}$ & $\mathbf{0 , 1 2 9 6}$ & 0,0051 & 0,1094 & 0,3127 & $\mathbf{0 , 1 1 5 7}$ & 0,0187 \\
\hline 2015 & $\underline{0,0103}$ & $\underline{0,0605}$ & 0,0639 & $\underline{0,1730}$ & $\mathbf{0 , 0 3 8 6}$ & $\mathbf{0 , 1 1 2 0}$ & 0,0069 & $\mathbf{0 , 1 1 4 2}$ & 0,3146 & $\mathbf{0 , 1 0 6 0}$ & 0,0400 \\
\hline 2016 & $\underline{0,0100}$ & $\underline{0,0571}$ & 0,0636 & $\underline{0,1675}$ & 0,0351 & $\mathbf{0 , 1 2 1 2}$ & 0,0065 & $\mathbf{0 , 1 1 4 3}$ & 0,3121 & $\mathbf{0 , 1 1 2 6}$ & 0,0159 \\
\hline 2017 & $\underline{0,0138}$ & $\underline{0,0463}$ & 0,0618 & $\underline{0,1628}$ & $\mathbf{0 , 0 4 2 7}$ & $\mathbf{0 , 1 1 6 1}$ & 0,0062 & $\mathbf{0 , 1 2 4 6}$ & $\mathbf{0 , 3 0 9 2}$ & $\mathbf{0 , 1 1 6 5}$ & 0,0257 \\
\hline
\end{tabular}

Objaśnienie: w tabeli czcionką pogrubioną zaznaczono wartości średnie najwyższe w grupach, a podkreślone są wartości najniższe.

Źródło: opracowanie własne na podstawie danych Eurostatu (2018)

Drugim państwem, dla którego w ocenianej dekadzie otrzymano grupę jednoelementową, jest Rumunia, która jest krajem rolniczym, choć zatrudnienie w tym sektorze wykazuje istotną tendencję spadkową ( $b=-0,0062)$ (tabela 3 i rycina 2). Z oceny tendencji zmian można wywnioskować, że zatrudnieni przenoszą się głównie do handlu $(b=0,0034)$, a korzystne tendencje to również wzrost udziałów zatrudnionych w informacji $(b=0,001)$, usługach profesjonalnych $(b=0,0022)$ i kulturze $(b=0,0013)$.

Tabela 4. Wskaźniki struktury zatrudnienia w sekcjach - Rumunia

\begin{tabular}{|c|c|c|c|c|c|c|c|c|c|c|c|}
\hline Rok & $S 1$ & $S 2$ & $S 3$ & $S 4$ & $S 5$ & $S 6$ & $S 7$ & S8 & S9 & S10 & $\begin{array}{c}\text { Zmiana } \\
\text { struktury }\end{array}$ \\
\hline 2008 & $\mathbf{0 , 2 4 9 8}$ & 0,2488 & 0,0841 & 0,1990 & $\underline{0,0134}$ & $\underline{0,0124}$ & $\underline{0,0017}$ & $\underline{0,0320}$ & $\underline{0,1398}$ & $\underline{0,0190}$ & - \\
\hline 2009 & $\mathbf{0 , 2 5 6 8}$ & 0,2325 & 0,0822 & 0,2015 & $\underline{0,0140}$ & $\underline{0,0139}$ & $\underline{0,0018}$ & $\underline{0,0338}$ & $\underline{0,1440}$ & $\underline{0,0195}$ & 0,0182 \\
\hline 2010 & $\mathbf{0 , 2 7 7 3}$ & 0,2181 & 0,0788 & 0,1959 & $\underline{0,0140}$ & $\underline{0,0149}$ & $\underline{0,0022}$ & $\underline{0,0350}$ & $\underline{0,1418}$ & $\underline{0,0221}$ & 0,0258 \\
\hline 2011 & $\mathbf{0 , 2 6 0 0}$ & 0,2215 & 0,0774 & 0,2013 & $\underline{0,0148}$ & $\underline{0,0165}$ & $\underline{0,0021}$ & $\underline{0,0374}$ & $\underline{0,1439}$ & $\underline{0,0253}$ & 0,0188 \\
\hline 2012 & $\mathbf{0 , 2 6 5 8}$ & 0,2175 & 0,0775 & 0,2030 & $\underline{0,0177}$ & $\underline{0,0154}$ & 0,0018 & $\underline{0,0373}$ & $\underline{0,1382}$ & $\underline{0,0259}$ & 0,0112 \\
\hline 2013 & $\mathbf{0 , 2 6 1 7}$ & $\mathbf{0 , 2 1 8 5}$ & 0,0769 & 0,2062 & $\underline{0,0175}$ & $\underline{0,0143}$ & $\underline{0,0022}$ & $\underline{0,0413}$ & $\underline{0,1344}$ & $\underline{0,0269}$ & 0,0096 \\
\hline 2014 & $\mathbf{0 , 2 5 4 0}$ & 0,2240 & 0,0774 & 0,2087 & $\underline{0,0176}$ & $\underline{0,0136}$ & $\underline{0,0025}$ & $\underline{0,0455}$ & $\underline{0,1294}$ & $\underline{0,0273}$ & 0,0135 \\
\hline 2015 & $\mathbf{0 , 2 3 0 7}$ & 0,2174 & $\mathbf{0 , 0 7 6 9}$ & 0,2193 & $\underline{0,0209}$ & $\underline{0,0127}$ & $\underline{0,0027}$ & $\underline{0,0471}$ & $\underline{0,1434}$ & $\underline{0,0288}$ & 0,0313 \\
\hline 2016 & $\mathbf{0 , 2 0 7 3}$ & 0,2256 & $\mathbf{0 , 0 8 2 6}$ & 0,2265 & $\underline{0,0205}$ & $\underline{0,0136}$ & $\underline{0,0022}$ & $\underline{0,0491}$ & $\underline{0,1425}$ & $\underline{0,0302}$ & 0,0253 \\
\hline 2017 & $\mathbf{0 , 2 0 2 8}$ & 0,2285 & $\mathbf{0 , 0 8 2 9}$ & 0,2267 & $\underline{0,0222}$ & $\underline{0,0139}$ & $\underline{0,0018}$ & $\underline{0,0501}$ & $\underline{0,1419}$ & $\underline{0,0293}$ & 0,0064 \\
\hline
\end{tabular}

Objaśnienie: w tabeli czcionką pogrubioną zaznaczono wartości średnie najwyższe w grupach, a podkreślone są wartości najniższe.

Źródło: opracowanie własne na podstawie danych Eurostatu (2018) 
Rycina 1. Struktury zatrudnienia w latach 2008-2017 - Luksemburg

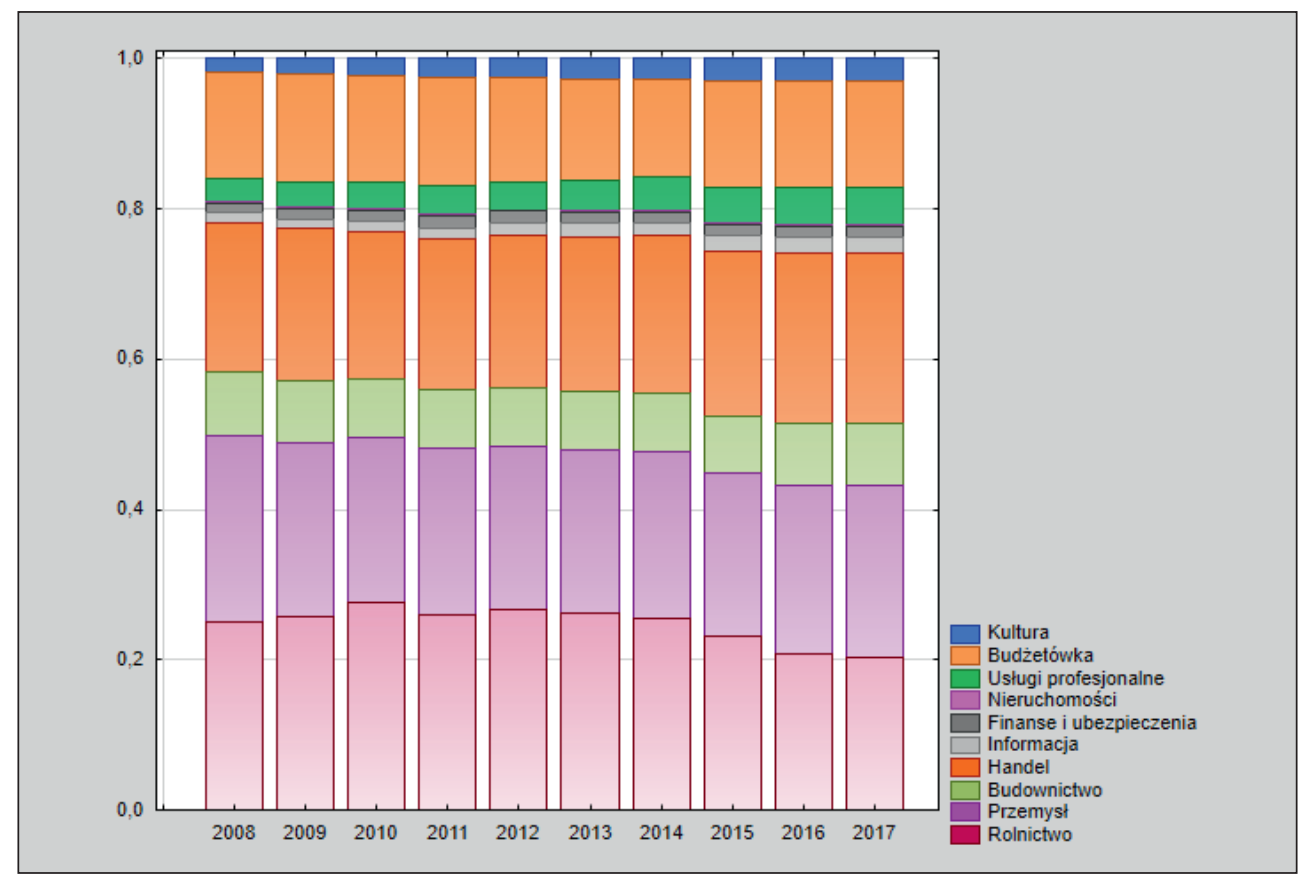

Źródło: opracowanie własne na podstawie danych Eurostatu (2018)

Rycina 2. Struktury zatrudnienia w latach 2008-2017 - Rumunia

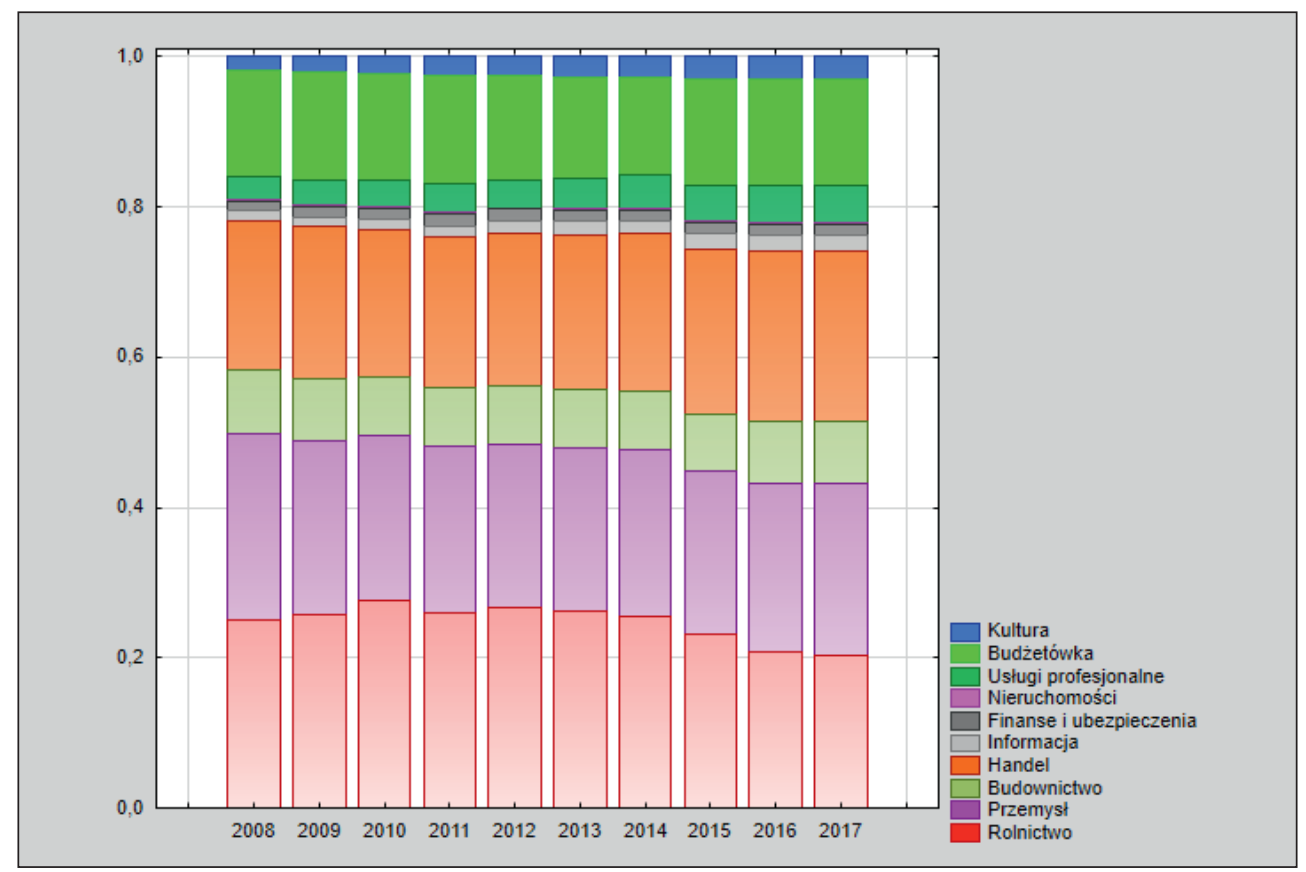

Źródło: opracowanie własne na podstawie danych Eurostatu (2018) 
Wśród pozostałych krajów wyróżniono trzy główne grupy państw o strukturach podobnych w niemal całym badanym okresie. Nazwa dla grupy A - Europa Zachodnia - jest umowna (trzykrotnie w grupie tej pojawia się Malta). Zasadniczy trzon grupy stanowią: Belgia, Dania, Francja, Holandia, Szwecja i Wielka Brytania. W tabeli 5 podano wartości średnie udziałów zatrudnionych w grupie w ocenianej dekadzie. Jeżeli chodzi o dominujące udziały, to należy wskazać zatrudnienie w nieruchomościach ( $\mathrm{z}$ tendencją wzrostową $\mathrm{b}=0,0003$ ) i w sferze budżetowej. W grupie A rośnie także udział zatrudnionych w usługach profesjonalnych $(b=0,0029)$, a spada udział zatrudnionych $w$ rolnictwie $(b=-0,004)$, przemyśle (najmocniej, $b=-0,0042$ ) i budownictwie $(b=-0,0008)$.

Tabela 5. Wartości średnie wskaźników struktury zatrudnienia w grupie A

\begin{tabular}{|c|c|c|c|c|c|c|c|c|c|c|c|}
\hline Rok & S1 & S2 & S3 & S4 & S5 & S6 & S7 & S8 & S9 & S10 & $\begin{array}{c}\text { Zmiana } \\
\text { struktury }\end{array}$ \\
\hline 2008 & 0,0219 & 0,1652 & $\underline{0,0727}$ & 0,2333 & $\mathbf{0 , 0 3 6 0}$ & 0,0324 & $\mathbf{0 , 0 0 8 8}$ & 0,0914 & 0,2885 & 0,0497 & - \\
\hline 2009 & 0,0232 & 0,1776 & 0,0714 & 0,2366 & 0,0333 & 0,0327 & 0,0072 & 0,0868 & 0,2791 & 0,0522 & 0,0470 \\
\hline 2010 & 0,0235 & 0,1398 & 0,0687 & 0,2259 & 0,0368 & 0,0305 & $\mathbf{0 , 0 0 9 3}$ & 0,0979 & $\mathbf{0 , 3 1 4 0}$ & 0,0536 & 0,0198 \\
\hline 2011 & 0,0226 & 0,1387 & 0,0689 & 0,2249 & 0,0371 & 0,0308 & $\mathbf{0 , 0 0 9 5}$ & $\mathbf{0 , 0 9 9 6}$ & $\mathbf{0 , 3 1 4 7}$ & 0,0533 & 0,0033 \\
\hline 2012 & 0,0229 & 0,1455 & 0,0652 & 0,2332 & 0,0392 & 0,0339 & 0,0085 & 0,0989 & 0,3006 & 0,0520 & 0,0207 \\
\hline 2013 & 0,0217 & 0,1340 & 0,0671 & 0,2250 & 0,0369 & 0,0307 & $\mathbf{0 , 0 1 0 1}$ & $\mathbf{0 , 1 0 7 8}$ & $\mathbf{0 , 3 1 3 0}$ & 0,0536 & 0,0264 \\
\hline 2014 & 0,0185 & 0,1276 & 0,0655 & 0,2268 & 0,0359 & 0,0323 & $\mathbf{0 , 0 1 1 0}$ & $\mathbf{0 , 1 1 0 9}$ & $\mathbf{0 , 3 2 0 5}$ & 0,0511 & 0,0147 \\
\hline 2015 & 0,0183 & 0,1277 & 0,0644 & 0,2292 & 0,0367 & 0,0317 & $\mathbf{0 , 0 1 0 8}$ & 0,1124 & $\mathbf{0 , 3 1 8 4}$ & 0,0505 & 0,0048 \\
\hline 2016 & 0,0208 & 0,1294 & 0,0655 & 0,2278 & $\mathbf{0 , 0 3 7 8}$ & 0,0296 & $\mathbf{0 , 0 1 0 6}$ & 0,1131 & $\mathbf{0 , 3 1 3 2}$ & 0,0532 & 0,0089 \\
\hline 2017 & 0,0201 & 0,1366 & 0,0663 & 0,2345 & 0,0391 & 0,0338 & $\mathbf{0 , 0 0 9 6}$ & 0,1105 & $\mathbf{0 , 2 9 6 3}$ & 0,0532 & 0,0211 \\
\hline
\end{tabular}

Objaśnienie: w tabeli czcionką pogrubioną zaznaczono wartości średnie najwyższe w grupach, a podkreślone są wartości najniższe.

Źródło: opracowanie własne na podstawie danych Eurostatu (2018)

W grupie B były w latach 2008-2017 głównie kraje postsocjalistyczne. Jej trzon stanowią Czechy, Węgry, Polska, Słowenia, Słowacja - jest to obszar zwarty terytorialnie. Dodatkowo w większości lat w grupie tej były Bułgaria, Estonia, Chorwacja i... Włochy, a incydentalnie pojawiały się Niemcy i Austria oraz trzykrotnie Portugalia. Średni udział zatrudnionych w przemyśle w tej grupie wskazuje, jakim dogmatem był w socjalizmie rozwój przemysłu - głównie ciężkiego. To byłe kraje bloku socjalistycznego przodują w zatrudnieniu w przemyśle i to bez tendencji zmniejszania się tego udziału - tabela 6. Maleje natomiast udział zatrudnionych w rolnictwie $(b=-0,0023)$ i budownictwie $(-0,0021)$. W krajach grupy B rośnie udział zatrudnionych w handlu ( $b=0,0007)$ - podobnie jak w Rumunii, także byłym kraju socjalistycznym. Tendencja wzrostowa w tej grupie dotyczy także udziału pracujących w usługach profesjonalnych $(b=0,0014)$ i sferze budżetowej $(b=0,0035)$.

Tabela 6. Wartości średnie wskaźników struktury zatrudnienia w grupie B

\begin{tabular}{|c|c|c|c|c|c|c|c|c|c|c|c|}
\hline Rok & S1 & S2 & S3 & S4 & S5 & S6 & S7 & S8 & S9 & S10 & $\begin{array}{c}\text { Zmiana } \\
\text { struktury }\end{array}$ \\
\hline 2008 & 0,0633 & $\mathbf{0 , 2 5 7 8}$ & 0,0929 & 0,2454 & 0,0231 & 0,0222 & 0,0061 & 0,0606 & 0,1913 & 0,0372 & - \\
\hline 2009 & 0,0633 & $\mathbf{0 , 2 4 2 9}$ & 0,0903 & 0,2485 & 0,0244 & 0,0234 & 0,0061 & 0,0628 & 0,2004 & 0,0378 & 0,0176 \\
\hline 2010 & 0,0644 & $\mathbf{0 , 2 3 3 7}$ & 0,0861 & 0,2476 & 0,0252 & 0,0226 & 0,0066 & 0,0653 & 0,2074 & 0,0411 & 0,0152 \\
\hline
\end{tabular}




\begin{tabular}{|l|l|l|l|l|l|l|l|l|l|l|l|}
\hline 2011 & 0,0749 & $\mathbf{0 , 2 5 1 9}$ & 0,0812 & 0,2459 & 0,0260 & 0,0245 & 0,0054 & 0,0603 & 0,1973 & 0,0325 & 0,0315 \\
\hline 2012 & 0,0648 & $\mathbf{0 , 2 4 5 5}$ & 0,0793 & 0,2469 & 0,0259 & 0,0246 & 0,0067 & 0,0647 & 0,2064 & 0,0352 & 0,0186 \\
\hline 2013 & 0,0584 & 0,2174 & 0,0767 & 0,2507 & 0,0261 & 0,0246 & 0,0087 & 0,0741 & 0,2192 & 0,0439 & 0,0370 \\
\hline 2014 & 0,0561 & $\mathbf{0 , 2 5 0 6}$ & $\mathbf{0 , 0 7 8 6}$ & 0,2321 & 0,0287 & 0,0223 & 0,0082 & 0,0685 & 0,2181 & 0,0368 & 0,0377 \\
\hline 2015 & 0,0636 & $\mathbf{0 , 2 2 9 1}$ & 0,0768 & 0,2505 & 0,0289 & 0,0209 & 0,0086 & 0,0680 & 0,2152 & 0,0382 & 0,0280 \\
\hline 2016 & 0,0357 & $\mathbf{0 , 2 3 2 0}$ & 0,0733 & 0,2400 & 0,0306 & 0,0247 & 0,0070 & 0,0802 & 0,2292 & 0,0472 & 0,0436 \\
\hline 2017 & 0,0503 & $\mathbf{0 , 2 7 1 6}$ & 0,0746 & 0,2243 & 0,0278 & 0,0221 & 0,0064 & 0,0679 & 0,2202 & 0,0346 & 0,0829 \\
\hline
\end{tabular}

Objaśnienie: w tabeli czcionką pogrubioną zaznaczono wartości średnie najwyższe w grupach, a podkreślone są wartości najniższe.

Źródło: opracowanie własne na podstawie danych Eurostatu (2018)

W kształtowaniu się grupy C charakterystyczna jest możliwość wydzielenia dwóch okresów: 2008-2012 i 2013-1017 (tabele 2 i 7). Szczególną zmianą jakościową jest opuszczenie tej grupy przez Litwę i Łotwę - w wyniku zmian struktury zatrudnienia w tych krajach. W skład grupy wchodzą głównie kraje śródziemnomorskie: w pierwszym okresie w trzonie grupy są Grecja i Hiszpania, a w drugim dochodzi do nich Cypr. Dodatkowo w pierwszym okresie typowymi były również wspomniane Litwa i Łotwa oraz Irlandia i Austria. Obok najwyższego od roku 2013 średniego udziału zatrudnionych $\mathrm{w}$ handlu ( $\mathrm{z}$ tendencją wzrostową $-\mathrm{b}=0,0050$ ) charakterystyczny jest $\mathrm{w}$ tym okresie najniższy przeciętny udział zatrudnionych w budownictwie (z tendencją spadkową - b =-0,0044).

Tabela 7. Wartości średnie wskaźników struktury zatrudnienia w grupie C

\begin{tabular}{|c|c|c|c|c|c|c|c|c|c|c|c|}
\hline Rok & S1 & S2 & S3 & S4 & S5 & S6 & S7 & S8 & S9 & S10 & $\begin{array}{c}\text { Zmiana } \\
\text { struktury }\end{array}$ \\
\hline 2008 & 0,0405 & 0,1452 & $\mathbf{0 , 1 0 8 1}$ & 0,2727 & 0,0293 & 0,0399 & 0,0064 & 0,0885 & 0,2044 & 0,0648 & - \\
\hline 2009 & 0,0702 & 0,1596 & 0,0869 & 0,2728 & 0,0258 & 0,0278 & 0,0068 & 0,0749 & 0,2215 & 0,0537 & 0,0616 \\
\hline 2010 & 0,0710 & 0,1512 & 0,0730 & 0,2767 & 0,0286 & 0,0292 & 0,0083 & 0,0793 & 0,2307 & 0,0521 & 0,0239 \\
\hline 2011 & 0,0753 & 0,1455 & $\underline{0,0651}$ & 0,2815 & 0,0293 & 0,0279 & 0,0083 & 0,0806 & 0,2340 & 0,0525 & 0,0149 \\
\hline 2012 & 0,0593 & 0,1748 & 0,0760 & 0,2654 & 0,0246 & 0,0257 & $\mathbf{0 , 0 1 0 2}$ & 0,0804 & 0,2253 & 0,0584 & 0,0480 \\
\hline 2013 & 0,0589 & 0,1324 & $\underline{0,0543}$ & $\mathbf{0 , 2 8 5 8}$ & 0,0360 & 0,0383 & 0,0042 & 0,0871 & 0,2434 & 0,0596 & 0,0704 \\
\hline 2014 & 0,0704 & 0,1135 & 0,0571 & $\mathbf{0 , 2 9 9 5}$ & 0,0261 & 0,0370 & 0,0035 & 0,0924 & 0,2234 & 0,0771 & 0,0508 \\
\hline 2015 & 0,0665 & 0,1137 & $\underline{0,0576}$ & $\mathbf{0 , 3 0 8 0}$ & 0,0256 & 0,0331 & 0,0039 & 0,0947 & 0,2221 & 0,0749 & 0,0118 \\
\hline 2016 & 0,0492 & 0,1206 & $\underline{0,0615}$ & $\mathbf{0 , 2 9 5 6}$ & 0,0340 & 0,0403 & 0,0054 & 0,0948 & 0,2341 & 0,0645 & 0,0401 \\
\hline 2017 & 0,0677 & 0,1024 & $\underline{\mathbf{0 , 0 6 1 4}}$ & $\mathbf{0 , 3 2 1 9}$ & 0,0263 & 0,0405 & 0,0049 & 0,0880 & 0,2217 & 0,0652 & 0,0456 \\
\hline
\end{tabular}

Objaśnienie: w tabeli czcionką pogrubioną zaznaczono wartości średnie najwyższe w grupach, a podkreślone są wartości najniższe.

Źródło: opracowanie własne na podstawie danych Eurostatu (2018)

Istotne (na poziomie 0,05) współczynniki kierunkowe trendów liniowych otrzymano także dla średnich udziałów zatrudnionych w przemyśle (średnioroczny spadek: $b=-0,0060$ ) i usługach profesjonalnych (średnioroczny wzrost: $b=0,0015$ ). Jest to grupa krajów o najbardziej zmiennej średniej strukturze - średnia miary zmiany to 0,0408. Dla grupy A było to 0,0347, dla B - 0,0336, zaś dla Luksemburga - 0,0232, a dla Rumunii - 0,0178. 


\section{ZAKOŃCZENIE}

Unia Europejska to - jak wynika z otrzymanej klasyfikacji krajów - obszar trzech typowych struktur zatrudnienia i dwóch odstających. W Luksemburgu widać zdecydowaną przewagę (nad innymi grupami krajów) w udziale zatrudnionych w finansach i ubezpieczeniach, zaś w Rumunii dominuje zatrudnienie w rolnictwie. Obserwuje się w ocenianej dekadzie - zmiany struktur w obu tych krajach, ale są one bardzo wolne i nieznaczne (niskie wartości wskaźników zmian struktury).

W krajach Europy Zachodniej relatywnie dużo osób zatrudnionych jest w nieruchomościach i sferze budżetowej, natomiast kraje postsocjalistyczne nie uporały się $\mathrm{z}$ dominacją zatrudnienia w przemyśle. Ogólnie wyróżnione struktury modelowe zmieniają się wolno, podobnie jak skład jednorodnych grup krajów.

Podsumowując, należy stwierdzić, że wykorzystanie wskaźnika niepodobieństwa (Chomątowski, Sokołowski, 1978) w połączeniu z taksonomiczną metodą aglomeracyjną najdalszego sąsiada pozwoliło zrealizować cel badawczy i wydzielić grupy krajów Unii Europejskiej podobne z uwagi na strukturę zatrudnienia w latach 2008-2017.

\section{Literatura \\ References}

Acemoglu, D. (2002). Technical change, inequality, and the labor market. Journal of Economic Literature, 40(1), 7-72.

Castellano, R, Musella, G., Punzo, G. (2017). Structure of the labour market and wage inequality: evidence from European countries. Quality \& Quantity: International Journal of Methodology, 51(5), 2191-2218.

Castellano, R, Musella, G., Punzo, G. (2019). Exploring changes in the employment structure and wage inequality in Western Europe using the unconditional quantile regression. Empirica, 46(2), 249-304.

Chomątowski, S., Sokołowski, A. (1978). Taksonomia struktur. Przegląd Statystyczny, 2, 217-226.

Eurostat (2018, 10 października). Pozyskano z http://appsso.eurostat.ec.europa.eu/nui/show. do?dataset=lfst_r_lfe2en2\&lang=en

Fernández-Macías, E. (2012). Job polarization in Europe? Changes in the employment structure and job quality, 1995-2007. Work and Occupations, 39(2), 157-182.

Gelbard, R., Goldman, O., Spiegler, I. (2007). Investigating diversity of clustering methods: An empirical comparison. Data \& Knowledge Engineering, 63, 155-166.

Goos, M, Manning, A, Salomons, A. (2009). Job polarization in Europe. American Economic Review, $99,58-63$.

Grabiński, T. (1980). Wielowymiarowa analiza porównawcza w badaniach dynamiki zjawisk ekonomicznych. Zeszyty Naukowe Akademii Ekonomicznej w Krakowie, seria specjalna: Monografie, 61.

Markowska, M., Sokołowski, A., Strahl, D. (2014). Taksonomia dynamiki zmian struktury zatrudnienia w nowoczesnym przemyśle i usługach w regionach Unii Europejskiej. Prace Komisji Geografii Przemysłu Polskiego Towarzystwa Geograficznego, 26, 46-64.

Walesiak, M. (1982). Metoda oceny podobieństwa struktur (na przykładzie struktury gałęziowej zatrudnienia w przemyśle uspołecznionym województw Polski w roku 1980). Wiadomości Statystyczne, 10(256), 11-14.

Małgorzata Markowska, dr hab., jest profesorem Uniwersytetu Ekonomicznego we Wrocławiu, na Wydziale Ekonomii i Finansów, w Katedrze Gospodarki Regionalnej. Jest członkiem Sekcji Klasyfikacji i Analizy Danych oraz Regional Studies Association. Realizuje badania naukowe dotyczące pomiaru, oceny, zróżnicowania, dynamiki zmian takich zjawisk, jak m.in.: rozwój, konkurencyjność, gospodarka oparta na wiedzy, inteligentne specjalizacje, konwergencja i innowacyjność w europejskiej przestrzeni na szczeblu regionalnym z wykorzystaniem metod ekonometrycznych. Jest autorem lub współautorem ponad 100 artykułów naukowych, 
monografii (Dynamiczna taksonomia innowacyjności regionów) oraz 25 rozdziałów w monografiach. Współpracowała przy realizacji 12 grantów finansowanych z funduszy ministerialnych i Narodowego Centrum Nauki oraz kilku projektów unijnych.

Małgorzata Markowska is an associate professor at the Regional Economics Chair of Wroclaw University of Economics and Business. She is a member of Polish Classification Society and Regional Studies Association. Her research deals with econometric measurement, evaluation, variability and dynamics of development, competitiveness, knowledge-based economy, smart specialisations, convergence and innovativeness in European regional space. As an author or a co-author she has published more than 100 papers and 25 chapters in books, and recently her own dissertation "Dynamic Taxonomy of Regions' Innovativeness". She took part in 12 research projects financed by the Polish National Centre of Science and European Union, and in projects for governmental, local administration and business units.

\title{
ORCID: 0000-0003-4879-0112
}

\section{Adres/address:}

\author{
Uniwersytet Ekonomiczny we Wrocławiu \\ Wydział Ekonomii i Finansów \\ Katedra Gospodarki Regionalnej \\ ul. Nowowiejska 3, 58-500 Jelenia Góra, Polska \\ e-mail: malgorzata.markowska@ue.wroc.pl
}

Danuta Strahl, prof. dr hab., jest profesorem Akademii WSB w Dąbrowie Górniczej, w Katedrze Zarządzania. Przez wiele lat kierowała Katedrą Gospodarki Regionalnej Uniwersytetu Ekonomicznego we Wrocławiu. Jest członkiem Komitetu, Statystyki i Ekonometrii Polskiej Akademii Nauk oraz Sekcji Klasyfikacji i Analizy Danych Polskiego Towarzystwa Statystycznego. Jej zainteresowania naukowe skupiają się na analizie regionalnej z wykorzystaniem metod ekonometrycznych. Jest autorem lub współautorem ponad 250 opracowań naukowych, w tym kilku monografii. Kierowała 15 grantami finansowanych z funduszy ministerialnych i Narodowego Centrum Nauki oraz brała udział w kilku projektach unijnych. Jest recenzentem wielu prac naukowych, w tym w przewodach habilitacyjnych i profesorskich.

Danuta Strahl is a full professor at WSB University in Dąbrowa Górnicza, Faculty of Management. For many years she was working as the Head of the Department of Regional Economy at Wrocław University of Economics. She is a member of the Statistics and Econometrics Committee of Polish Academy of Sciences and the Section of Classification and Data Analysis of Polish Statistical Association. Her research interests are focused on regional analysis using econometric methods. She is an author and a co-author of over 250 research studies, including several monographs. She supervised 15 grants financed by the Ministry and the National Science Centre funds and participated in several European Union projects. She is a reviewer of many academic papers, including postdoctoral and professorship dissertations.

\section{ORCID: 0000-0001-5036-5823}

\section{Adres/address:}

\author{
Akademia WSB w Dąbrowie Górniczej \\ Wydział Zarządzania \\ Katedra Zarządzania \\ ul. Cieplaka 1c, 41-300 Dąbrowa Górnicza, Polska \\ e-mail: dstrahl@wsb.edu.pl
}

Elżbieta Sobczak, dr hab., jest zatrudniona na stanowisku profesora nadzwyczajnego w Uniwersytecie Ekonomicznym we Wrocławiu, na Wydziale Ekonomii i Finansów, w Katedrze Gospodarki Regionalnej. Do jej głównych zainteresowań badawczych należą metody ilościowe w ekonomii, klasyfikacja i analiza danych i wielowymiarowa analiza statystyczna w badaniach regionalnych. Interesuje się również ekonometryczną analizą regionalną i metodami segmentacji rynków zagranicznych, konkurencyjnością, gospodarką opartą na wiedzy, inteligentnymi specjalizacjami, konwergencją i innowacyjnością w europejskiej przestrzeni regionalnej. Jako autorka lub współautorka opublikowała ponad 100 artykułów naukowych, 20 rozdziałów w monografiach oraz monografię autorską pt. Segmentacja rynków zagranicznych. Jest członkiem polskiej Sekcji Klasyfikacji i Analizy Danych (SKAD) i polskiej sekcji Regional Studies Association (RSA). 
Elżbieta Sobczak is an associate professor at Wroclaw University of Economics and Business, Department of the Regional Economics. Her research interests include quantitative methods in economics, classification and data analysis, multivariate statistical analysis in regional research. She is also interested in econometric regional analysis and segmentation methods of foreign markets, competitiveness, knowledge-based economy, smart specialisations, convergence and innovativeness in European regional space. As an author or a co-author she has published more than 100 papers and 20 chapters in books, and her own dissertation "Segmentation of foreign markets". She is a member of Polish Classification Society (SKAD), and Polish section of Regional Studies Association (RSA).

\title{
ORCID: 0000-0003-1912-7493
}

\section{Adres/address:}

\author{
Uniwersytet Ekonomiczny we Wrocławiu \\ Wydział Ekonomii i Finansów \\ Katedra Gospodarki Regionalnej \\ ul. Nowowiejska 3, 58-500 Jelenia Góra, Polska \\ e-mail: elzbieta.sobczak@ue.wroc.pl
}

Petr Hlaváček, doktor inżynier, jest profesorem nadzwyczajnym na Uniwersytecie im. J.E. Purkyně w Ústí nad Labem, na Wydziale Nauk Społeczno-Ekonomicznych, w Katedrze Rozwoju Regionalnego i Administracji Publicznej. Jest członkiem Regional Studies Association i Czeskiego Towarzystwa Geograficznego. Jego badania koncentrują się na rozwoju regionalnym i miejskim, regionalnej gospodarce i polityce, bezpośrednich inwestycjach zagranicznych w Europie Środkowej i regionalnych systemach innowacji. Jest autorem lub współautorem ponad 50 artykułów naukowych i rozdziałów w kilku monografiach. Był zaangażowany w koordynację lub współpracował przy realizacji 11 projektów badawczych lub grantów, finansowanych przez Agencję Grantową Republiki Czeskiej, Unię Europejską, uniwersytet lub regionalne i lokalne jednostki administracyjne. Pracuje również jako ekspert do oceny projektów Ministerstwa Edukacji, Młodzieży i Sportu.

Petr Hlaváček is a full professor at Jan Evangelista Purkyně University in Ústí nad Labem, Faculty of Social and Economic Studies, Department of Regional Development and Public Administration. He is a member of Regional Studies Association and Czech Geographical Society. His main research is focused on regional and urban development, regional economy and policy, foreign direct investments in Central Europe and regional innovation systems. He is an author or a co-author more than 50 papers and chapters in books and a few monographs. He was involved in the coordination or cooperation of 11 research projects or grants, financed by Grant Agency of the Czech Republic, European Union, university or regional and local administrative units. He also works as a expert for evaluation of project of Ministry of Education, Youth and Sports.

ORCID: 0000-0002-3922-5739

\section{Adres/address:}

Univerzita J.E. Purkyně v Ústí nad Labem

Fakulta sociálně ekonomická

Moskevská 54, 40096 Ústí nad Labem, Czechy

e-mail: petr.hlavacek@ujep.cz 